\title{
Possible age of crystallization of pyrope from the Stockdale kimberlite, Kansas, U. S. A.
}

\author{
Douglas G. BROOKINS \\ Department of Geology, Kansas State University \\ Manhattan, Kansas 66502, U. S. A.
}

(Received August 5, 1969)

\begin{abstract}
A possible age of $745 \pm 100$ m.y. (using 50b.y. = half life of ${ }^{87} \mathrm{Rb}$ ) has been determined for pyrope from the Stockdale kimberlite assuming an upper mantle initial ${ }^{87} \mathrm{Sr} /{ }^{86} \mathrm{Sr}$ ratio of $0.702 \pm 0.001$. Despite the large error associated with this age it clearly demonstrates that the pyrope crystallized long before its final emplacement which is set at $\leqq 100$ m.y. Allowance for crustal and mantle contamination and other sources of error have been carefully considered in this determination.
\end{abstract}

\section{INTRODUCTION}

Pyrope from the Stockdale kimberlite, Riley County, Kansas $\left(39^{\circ} 15^{\prime} 40^{\prime \prime}\right.$ N.; $96^{\circ} 42^{\prime} 08^{\prime \prime}$ W.) has been identified and described by several investigators (BAGROWSKI, 1941; EAstwood and Brookins, 1965; Rosa and Brookins, 1966; Brookins, 1967a). A purplish-red variety occurs most frequently, but a green variety (composition unknown, but more Cr-rich than the purplish-red variety) has also been noted. The former is somewhat variable in composition (as indicated by ranges in refractive index and unit cell measurements) but has an average chemical composition of $\mathrm{Mg}_{2.22} \mathrm{Fe}_{0.46^{-}}$ $\mathrm{Ca}_{0.29} \mathrm{Al}_{1.76} \mathrm{Fe}_{0.08} \mathrm{Cr}_{0.14} \mathrm{Si}_{2.98} \mathrm{O}_{12}$ (BROOKINS, 1967a). Because of its abundance it has been selected for $\mathrm{Rb}-\mathrm{Sr}$ age study despite the facts that it is often completely or partially rimmed by kelyphite of unknown composition and contains fractures filled with carbonates. In addition, minute inclusions of rutile and other minerals are occasionally noted. It has been recently demonstrated by ERLANK (1969) and ALLSOPP et al. (1969) that high ${ }^{87} \mathrm{Sr} /{ }^{86} \mathrm{Sr}$ ratios and high $\mathrm{K}$ (and therefore $\mathrm{Rb}$ ) values are found in kelyphite, intergranular material, and included material associated with eclogitic garnets from other kimberlites, hence great care must be taken to either purify the pyrope completely or attempt to correct the age measurement with proper consideration of possible contamination and other factors.

The Stockdale kimberlite outcrops over approximately 500 square yards and magnetometer surveys have shown it to be a pipe-like body dipping steeply to the southeast. It intrudes Lower Permian limestones and shales but is thought to be 
post-Lower Cretaceous in age because pronounced joint sets found in both Lower Cretaceous and Lower Permian rocks of Riley County are absent in the kimberlite, whereas a younger set of joints occurs in the kimberlite as well as in the older rocks (Brookins, 1969). This indicates a probable maximum age of emplacement of approximately $100 \mathrm{~m} . \mathrm{y} .$, a date not inconsistent with other kimberlitic emplacement in North America. In addition to pyrope, a typical kimberlitic assemblage of ilmenite, phlogopite, two pyroxenes, and olivine is found in a matrix of magnetite-perovskiteapatite bearing serpentine and carbonate minerals. The pyroxenes and olivine (Fo-92) have been largely serpentinized and/or replaced by calcite, phlogopite has been almost completely altered to chlorite and vermiculite, and ilmenite and perovskite are commonly rimmed by leucoxene. The kimberlite is highly brecciated due to the presence of numerous inclusions, most of which consist of unaltered to partially altered locally derived fragments of shale and limestone. Other recognizable inclusions include eclogites, gabbros, metagabbros, granulites, spinel lherzolites, and diorites. Inclusions of gneiss, schist, and acid igneous rocks are rare and highly altered. The paucity of acidic igneous inclusions is odd in that much of the Precambrian basement of this section of Kansas consists of granitic and granodioritic rocks (ColE et al., 1965). Much of the carbonate material is of a sedimentary origin, but petrographic study indicates that some may have been carbonatitic in origin; and carbonatitic calcite and dolomite have been found in three of the other four kimberlites in Riley County by BROOKINS (1967b).

\section{ANALYTiCAL METHODS}

Purification of the pyrope involved handpicking apparently pure grains from a $-40 \sim+100$ mesh crushed fraction using a binocular microscope. Kelyphite is readily identified by its green color and thus relatively easy to avoid, as are obviously fractured grains (which probably contain abundant carbonate of sedimentary and/or carbonatitic origin). Pyrope containing microscopic impurities was probably not completely removed, a point to be discussed later in this report. Approximately $7 \mathrm{~g}$ of pyrope were purified in this fashion and crushed to -325 mesh. Two $0.5 \mathrm{~g}$ aliquots were then leached with $100 \mathrm{ml}$ vycor distilled $0.05 \mathrm{~N} \mathrm{HCl}$ with occasional stirring for $24 \mathrm{hr}$ to test for contaminants. The samples were filtered and washed with deionized water several times and the filtrate evaporated to dryness, cooled, and redissolved in $5 \mathrm{ml}$ of $0.05 \mathrm{~N}$ $\mathrm{HCl}$ and analyzed for $\mathrm{K}$ and $\mathrm{Ca}$ by atomic absorption. Both aliquots showed less than $0.01 \mu \mathrm{g} / \mathrm{ml} \mathrm{Ca}$ and less than $0.005 \mu \mathrm{g} / \mathrm{ml} \mathrm{K}$. These results indicate that at least the surface of the crushed aliquots does not contain enough $\mathrm{Sr}$ or $\mathrm{Rb}$ to pose a contamination problem presuming that $\mathrm{Ca}>\mathrm{Sr}$ and $\mathrm{K}>\mathrm{Rb}$.

One gram of pyrope was dissolved in a mixture of $20 \mathrm{ml}: 6 \mathrm{ml}$ reagent grade $\mathrm{HF}$ : vycor distilled $\mathrm{HClO}_{4}$ in a teflon dish and evaporated to dryness, digested in 
$80 \mathrm{ml}$ of a $50: 50$ mixture of vycor distilled $2 \mathrm{~N} \mathrm{HCl}$ :deionized water and condensed to about $10 \mathrm{ml}$, and allowed to cool for $24 \mathrm{hr}$. Radioactive ${ }^{85} \mathrm{Sr}$ was then added and the sample filtered and $\mathrm{Sr}$ separated by ion exchange techniques (vycor column, quartz wool filter) using vycor distilled $2 \mathrm{~N} \mathrm{HCl}$ as eluant. The samples were collected in polypropylene beakers, evaporated to dryness, and the contents of those showing any gamma activity were concentrated and evaporated to dryness in a teflon dish. Final fusion was carried out in a $4 \mathrm{ml}$ vycor beaker.

Two $2.0000 \mathrm{~g}$ aliquots of pyrope were treated in the same manner after the addition of $5 \mathrm{ml}$ dilute ${ }^{87} \mathrm{Rb}$-enriched spike $(10.40 \pm 0.02 \mu \mathrm{g} / \mathrm{ml})$ and $5 \mathrm{ml}$ dilute ${ }^{86} \mathrm{Sr}$ enriched spike $(9.59 \pm 0.05 \mu \mathrm{g} / \mathrm{ml})$ to each prior to dissolution, and $\mathrm{Rb}$ and $\mathrm{Sr}$ were separated by ion exchange techniques. The choice of amount of spikes added was unfortunate, but greater amounts of both $\mathrm{Rb}$ and $\mathrm{Sr}$ were anticipated as the isotopic analysis had been completed by this time (see discussion later in this report).

The mass spectrometer used was a Nier-type $6^{\prime \prime} 60^{\circ}$ single filament surface ionization direction focussing instrument with Faraday cup collection and amplification by a vibrating reed electrometer and a strip recorder with expanded scale.

\section{Results}

The blank data are shown in Table 1 and the analytical results in Table 2. All ${ }^{87} \mathrm{Sr} /{ }^{86} \mathrm{Sr}$ data have been normalized to ${ }^{86} \mathrm{Sr} /{ }^{88} \mathrm{Sr}=0.1194$, and the error about a single determination is $\pm 0.0005(\bar{\sigma})$ based on replicate analyses of the Eimer and Amend (lot. no. 492327) Standard $\mathrm{SrCO}_{3}$. An error of \pm 0.0007 has been assigned to the corrected ${ }^{87} \mathrm{Sr} /{ }^{86} \mathrm{Sr}$ value of 0.7186 due to the uncertainty in the blank Sr.

It is assumed that the pyrope crystallized in the upper mantle, perhaps as deep as 130 to $150 \mathrm{~km}$ (probable stability range for diamond according to MEYER and BOYD, 1968), but the ${ }^{87} \mathrm{Sr} /{ }^{86} \mathrm{Sr}$ ratios in source rocks at these depths is not known. I have chosen the value of initial ${ }^{87} \mathrm{Sr} /{ }^{86} \mathrm{Sr}=0.702 \pm 0.001$ which is reasonable in the light of recent work (HuRLEy, 1967). Using this value and a half life of ${ }^{87} \mathrm{Rb}=50 \mathrm{~b} . \mathrm{y}$. an age of $745 \pm 100 \mathrm{~m}$.y. is calculated for the Stockdale pyrope, the large error being due to the uncertainties in analytical techniques, blanks, spikes (particularly when one

Table 1. Blank data

\begin{tabular}{cccccc}
\hline Run & $\mathrm{Rb}(\mu \mathrm{g})$ & $\mathrm{Sr}(\mu \mathrm{g})$ & ${ }^{87} \mathrm{Sr} /{ }^{86} \mathrm{Sr}$ & $\mathrm{Rb}(\mathrm{ppm})^{*}$ & $\mathrm{Sr}(\mathrm{ppm})^{*}$ \\
\hline 1 & - & - & $0.7080 \pm 0.0005$ & - & - \\
2 & 0.078 & 0.100 & - & 0.039 & 0.050 \\
3 & 0.082 & 0.100 & - & 0.041 & 0.050 \\
4 & - & 0.102 & - & - & 0.051 \\
\hline
\end{tabular}

* Assuming a $2.0 \mathrm{~g}$ sample weight as used in the actual analysis. 
Table 2.

\begin{tabular}{lcccc}
\hline Sample & $\mathrm{Rb}(\mathrm{ppm})$ & $\mathrm{Sr}(\mathrm{ppm})$ & ${ }^{87} \mathrm{Rb} /{ }^{86} \mathrm{Sr}$ & ${ }^{87} \mathrm{Sr} /{ }^{86} \mathrm{Sr}$ \\
\hline A. Uncorrected & & & & \\
Split 1 & - & - & - & $0.7175 \pm 0.0005$ \\
Split 2 & $0.273 \pm 0.005$ & $0.465 \pm 0.010$ & $1.70 \pm 0.05$ & - \\
Split 3 & $0.270 \pm 0.005$ & $0.475 \pm 0.010$ & $1.65 \pm 0.05$ & - \\
B. Corrected for blanks* & - & & & \\
Split 1 & - & - & - & $0.7186 \pm 0.0007$ \\
Split 2 & $0.233 \pm 0.010$ & $0.415 \pm 0.020$ & $1.63 \pm 0.07$ & - \\
Split 3 & $0.230 \pm 0.010$ & $0.425 \pm 0.020$ & $1.57 \pm 0.07$ & - \\
Averages & $0.2315 \pm 0.010$ & $0.420 \pm 0.020$ & $1.60 \pm 0.07$ & $0.7186 \pm 0.0007$ \\
\hline
\end{tabular}

* Using data from Table 1. Increased uncertainty reflects the added uncertainty due to blank correction.

notes the overspiking), and the assumed values for initial ${ }^{87} \mathrm{Sr} /{ }^{86} \mathrm{Sr}$ and the half life of ${ }^{87} \mathrm{Rb}$. The precision of the replicate analyses is high, however, and the data suggest a much older age of crystallization for the pyrope than its final age of emplacement.

\section{Discussion AND CONCLUSIONS}

This ancient age can be explained in numerous ways, and some possible models are: (a) The original magma pocket possessed an anomalously high ${ }^{87} \mathrm{Sr} /{ }^{86} \mathrm{Sr}$ ratio and the $\mathrm{Rb}$ was added by contamination at a much later time and the age is accidentally high. (b) The $\mathrm{Rb}$ was trapped in the pyrope during original crystallization from an initial low ${ }^{87} \mathrm{Sr} /{ }^{86} \mathrm{Sr}$ magma and the age is real. (c) Identical to (b) except that some radiogenic ${ }^{87} \mathrm{Sr}$ and/or $\mathrm{Rb}$ has been lost from the system subsequent to original crystallization and the age is too low. (d) Radiogenic ${ }^{87} \mathrm{Sr}$ has been added to the pyrope from some other source after crystallization, possibly during kelyphitization, by thermal diffusion and partial recrystallization and the age is too high. (e) The high ${ }^{87} \mathrm{Sr} /{ }^{86} \mathrm{Sr}$ ratio and the $\mathrm{Rb}$ content of the pyrope are purely accidental due to crustal contamination.

Let us examine these few models in order. Pockets of magma (a) possessing very high ${ }^{87} \mathrm{Sr} /{ }^{86} \mathrm{Sr}$ ratios in the upper mantle may be a reality, particularly if some K-rich phases such as phlogopite (stable to at least $96 \mathrm{~kb}$ and $1,000^{\circ} \mathrm{C}$ when $P_{\text {water }}=P_{\text {total }}$ according to MARKOv et al., 1966; and KUSHIRO et al., 1967) were to break down as pyrope was crystallizing. Granted that this may seem a remote possibility, but then kimberlites are rare rocks and do possess relatively high $\mathrm{K}$ contents when compared with other ultramafic rocks. Model (b) readily explains the age as does model (c), and either model is probable. If accepted, then the $745 \pm 100 \mathrm{~m}$.y. pyrope date is a 
minimum time of crystallization. Model (d) is also possible, but less likely than (b) or (c) because the radiogenic ${ }^{87} \mathrm{Sr}$ would tend to be concentrated near the periphery of the pyrope and hence more likely to be lost during its subsequent history. Model (e) is the usual suggested explanation for many similar gechronological studies and cannot be ruled out, except that the presence of unaltered inclusions of deep-seated gabbroic rocks indicates that crustal injection was rapid, thus decreasing the chances for such a model, particularly when one is considering a highly stable phase such as pyrope. Pre-emplacement ages of primary kimberlite minerals are also known from Russian and African kimberlites (see discussion in Edwards and Howkins, 1966).

Many investigators have been studying eclogitic inclusions and their constituent minerals (see, for example, Erlank, 1969; Allsopp et al., 1969; and Mitchell et al., 1969) yet the primary kimberlitic minerals, with the exception of phlogopite (which is often altered), are often ignored. This brief study indicates that more emphasis should be placed on the kimberlite minerals, and that attempts at dating kelyphite as well should be undertaken.

\section{ACKNOWLEDGMENTS}

This study was supported by the National Science Foundation (Grants GA-317, GA-893) and by Kansas State University.

\section{REFERENCES}

AllsopP, H. L., Nicolaysen, L. O., and HaHN-Weinheimer, P. (1969) Rb/K ratios and Sr isotopic compositions of minerals in eclogitic and peridotitic rocks. Earth Plan. Sci. Letters 5, 231-244.

BAGRowSKI, B. P. (1941) Pyrope garnet versus ruby spinel in Kansas. Amer. Mineralogist 26, 675-676.

BRookINS, D. G. (1967a) Re-examination of pyrope from the Stockdale kimberlite, Riley County, Kansas. Mineral. Mag. 36, 450-452.

BROOKINS, D. G. (1967b) The strontium geochemistry of carbonates in kimberlites and limestones from Riley County, Kansas. Earth Plan. Sci. Letters 2, 235-240.

BRookINS, D. G. (1969) The significance of K - Ar dates on altered kimberlitic phlogopite from Riley County, Kansas. J. Geol. 77, 102-107.

Cole, V. B., Merriam, D. F., and Hambleton, W. W. (1965) Final report of the Kansas Geological Society Basement Rock Committee and list of Kansas wells drilled into Precambrian rocks. Kansas State Geol. Survey Spec. Distr. Pub. 25, 48 p.

EASTwOOD, R. L. and BRookINS, D. G. (1965) A spectrochemical investigation of the Bala and Stockdale intrusions, Riley County, Kansas. Trans. Ks. Acad. Sci. 68, 72-86.

EDWARDS, C. B., and HowkinS, J. B. (1966) Kimberlites in Tanganyika with special reference to the Mwadui occurrence. Ec. Geol. 61, 537-554.

ERLANK, A. J. (1969) Microprobe investigation of potassium distribution in mafic and ultramafic nodules. Trans. Amer. Geophys. Union 50, 343.

HURLEY, P. M. (1967) ${ }^{87} \mathrm{Rb}^{87} \mathrm{Sr}$ relationships in the differentiation of the mantle. in Ultramafic 
and related rocks, P. J. Wyllie, ed., John Wiley \& Sons, Inc., N. Y., 372-376.

KuSHIRO, I., SYONO, Y., and AKIMOTO, S. (1967) Stability of phlogopite at high pressures and possible presence of phlogopite in the earth's upper mantle. Earth Plan. Sci. Letters 3, 197-203.

Markov, V. K., Petrov, V. P., Delitsin, I. S., and RYabini, Y. N. (1966) Phlogopite transformations at high pressures and temperatures. Izv. Akad. Nauk. SSSR, Geol. Ser. 6, 10-20.

MEYER, H. O. A., and BOYD, F. R. (1968) Mineral inclusions in diamonds. Carnegie Inst. Yrbk. 67, 130-134.

Mitchell, R. H., CROCKETT, J. H., and MCNUTT, R. H. (1969) Isotopic composition of strontium in some South African kimberlites. Trans. Amer. Geophys. Union 50, 346.

RosA, F., and BRookins, D. G. (1966) The mineralogy of the Stockdale kimberlite pipe, Riley County, Kansas. Trans. Ks. Acad. Sci. 69, 335-344. 